\title{
COMMENT
}

\section{A NOTE ON SOME ASPECTS OF THE NUREMBERG DEBATE}

\author{
BERNARD D. MELTZER*
}

History has not and cannot for a long time render its verdict on the Nuremberg trials. This verdict will, it is clear, depend less on Nuremberg and on the events which preceded it than on events which are to come. But debate on the issues raised by the trial is in full swing. It has been hailed as a significant contribution to international law, order, and justice. It has been attacked with a variety of objections: ex post facto, novelty and confusion, threat to the great traditions of Anglo-American justice, disrepute for the judiciary, the power of the victors masquerading as law, a barrier to the development of a democratic legal order in Germany.2

Professor Max Rheinstein in the February issue of this Review ${ }^{3}$ joined the men who have attacked the legal and moral foundations of this trial. His views are representative of the whole current of criticism. Certain issues raised by the debate may be clarified by an examination of his position and the problems which it suggests. ${ }^{4}$

His first objection is the conventional one, that the trials involved punishment in violation of the rule of mulla poena sine lege; that is, they involved the imposition of punishment on the basis of a standard retro-

* Professorial Lecturer, University of Chicago Law School; formerly Trial Counsel, Office of United States Chief of Counsel for Prosecution of Axis War Criminality.

See e.g., Stimson, The Nuremberg Trial: Landmark in Law, 25 Foreign Affairs Mag. I 79 (1947).

=See The Nurnberg Novelty, 32 Fortune I40 (Dec., I945); The Nurnberg Confusion, 34 Fortune I20 (Dec., I946); Vambery, The Law of the Tribunal, I6 3 Nation 400 (I946); Pekelis, To the Nuremberg Court, II5 New Republic 232 (I946); Wyzanski, Nuremberg, a Fair Trial? I77 Atlantic Monthly 66 (April, x946); but cf. Wyzanski, Nuremberg in Retrospect, I78 Atlantic Monthly 56 (Dec., I946).

3 Professor Rheinstein stated his position in a review of Glueck, The Nuremberg Trial and Aggressive War (1946), x4 Univ. Chi. L. Rev. 3 I9 (I947).

4 This comment, which began as a brief discussion of Professor Rheinstein's objections to Nuremberg, has outrageously expanded into a comment on related objections urged by other critics. I wish to make it clear that I do not intend to associate Professor Rheinstein with any of the views which I attribute to other critics unless I explicitly state that these views are shared by Professor Rheinstein. 
actively defined. In addition, Professor Rheinstein intimates that the trials were objectionable because the Germans were punished for acts which were not only legal but were praiseworthy under the Nazi system. He also suggests that the trials have impeded our attempt to establish a democratic legal order in Germany. Finally, he sees in Nuremberg the cause of allegedly arbitrary action by the German Länder (States) acting under the direction of the United States Military Government.

Although the ex post facto objection does not, in my judgment, raise the crucial problem, it deserves examination because it has been the heavy artillery of the critics' attack. The objection is in essence that the pre-war treaties, commentaries, and other sources of international law did not constitute a clear international agreement that individuals who launched an aggressive war were to be punished as criminals. This argument generally rests on the premise that, if the trials involved the application of a retroactive standard, they deserve condemnation.

There would be little quarrel with this premise as applied to our own domestic law. However, reflection on the character of international law and the purpose and tradition behind the rule against retroactivity suggests that the premise should not be mechanically applied to Nuremberg. The rule has not been automatically applied in the field of international law and should not be. There is the example of the Hague Convention which prescribed rules designed to restrain the barbarity of war. Although this convention did not provide for punishment of individual offenders, such punishment has customarily been inflicted for violations of the convention's commands. ${ }^{5}$ Pirates, to cite another familiar example, have been subjected to individual punishment even in the absence of prior domestic or international legislation providing for punishment or defining its extent. ${ }^{6}$

The differing applicability of the rule mulla poena sine lege in international and municipal law, respectively, has the sanction of common sense as well as of history. The rule has flourished in comparatively well developed legal systems. ${ }^{7}$ It has not been applied in primitive and immature systems of law. During the early development of the common-law system, offenses which shocked the moral sense of the community were retrospectively transformed into crimes for which individual punishment was exacted. ${ }^{8}$ Indeed, Professor Radin tells us:

\footnotetext{
${ }^{5}$ See Transcript of International Military Tribunal, 16874 (1946).

${ }^{6}$ Radin, International Crimes, 32 Iowa L. Rev. 33, 4I (I946).

7 Hall, Nulla Poena sine Lege, 47 Yale L.J. I65, I78-80 (1937).

${ }^{8}$ Radin, Anglo-American Legal History 24I-42 (I936).
} 
Most of the acts which are unmistakably crimes, acts like murder, robbery, rape, were punished for centuries although the detailed determination of just what acts were punishable under these names was found merely in custom and tradition and not in a statute. In other words, those who killed and robbed were punished because ordinary common sense and a general standard of conduct made their acts wrongful and dangerous and the perpetrators were not heard to say that they did not know the character of their acts because no law had specifically prohibited them.9

The strict and automatic application of the rule against retroactivity to an undeveloped legal system would, of course, have widened the gap between the developing moral sense of the community and its lagging legal institutions. It would have made society the prisoner of its own particularly limited legal history. It is a luxury which an immature legal system cannot afford. The moral in connection with our unfortunately primitive system of international law requires no extended elaboration..$^{10}$

The mechanical application of mulla poena sine lege to protect the Nazi instigators of aggression would be inconsistent not only with the history of the doctrine, but also with its purpose. Behind the doctrine is the idea that it is unjust to punish one who at the time he acted reasonably believed that his conduct was not culpable..$^{1 x}$ But the Nazis had read and had not repudiated the Kellogg-Briand Pact, which had been solemnly signed by an earlier German government. They were aware of the other international formulations which either stated explicitly or implied that aggressive war was an international crime. ${ }^{12}$ The Nazis, whatever their contempt

9 Radin, War Crimes and the Crime of War, 2I Va. Q. Rev. 497, 508 (r945).

ro In this connection, Mr. Justice Jackson in his opening statement argued: " $I t$ is true, of course, that we have no judicial precedent for the Charter. But International Law is more than a scholarly collection of abstract and immutable principles. It is an outgrowth of treaties and agreements between nations and of accepted customs. Yet every custom has its origin in some single act, and every agreement has to be initiated by the action of some state. Unless we are prepared to abandon every principle of growth for International Law, we cannot deny that our own day has the right to institute customs and to conclude agreements that will themselves become sources of a newer and strengthened International Law. International $\mathrm{Law}$ is not capable of development by the normal processes of legislation for there is no continuing international legislative authority. Innovations and revisions in International Law are brought about by the action of governments designed to meet a change in circumstances. It grows, as did the Common Law, through decisions reached from time to time in adapting settled principles to new situations. The fact is that when the law evolves by the case method, as did the Common Law and as International Law must do, if it is to advance at all, it advances at the expense of those who wrongly guessed the law and learned too late their error. The law, so far as International Law can be decreed, had been clearly pronounced when these acts took place. Hence, I am not disturbed by the lack of judicial precedent for the inquiry we propose to conduct." I Nazi Conspiracy and Aggression I65 (Office of United States Chief of Council for Prosecution of Axis Criminality, 1946), hereinafter cited as "Nazi Conspiracy and Aggression."

$\therefore$ Hall, op. cit. supra note 7 , at $x 7 x-72$.

${ }_{12}$ An impressive list of such formulations are discussed in Glueck, The Nuremberg Trial and Aggressive War 25-34 (1946). 
for the values of Western civilization, knew that under these previously defined international standards the launching of a modern war of aggression was an act of the highest culpability. Although in their domestic affairs they glorified war-making, in their international relations, prior to the attack on Poland, they pretended to defer to the world's repugnance for war. Thus they repeatedly assured their neighbors and interested powers like the United States that they intended no aggression. To shield the Nazi leaders by applying a principle designed to protect men who acted without knowledge of their culpability would involve a monumental perversion of justice. The mechanical application of a Latin phrase, however important the value it enshrines, should not be permitted to victimize the moral sense of the peoples of the world.

Nuremberg does not, in this view, stand or fall on the validity of the charge that the penalization of aggressive war had an ex post facto aspect. Even if this charge were conceded, it would not foreclose the consideration which appears to be the overriding one: Where, as in the case of the Nazi aggression, there has been a grave, deliberate, and flagrant violation of widely accepted standards; where such a violation necessarily involved death and misery for millions, it is more important to condemn and punish such conduct than to follow literally the principle against retroactivity. It is, to put it differently, more important to vindicate and crystallize the world's repugnance for aggressive war than mechanically to apply nulla poena sine lege.

It was reflection on these considerations which impelled Judge Wyzanski to withdraw his previous criticism and to approve the Charter's ${ }^{13}$ condemnation of aggressive war as a crime. Judge Wyzanski also has offered a related explanation for the change in his position:

The reasons for my change are that the failure of the international community to attach the criminal label to such universally condemned conduct would be more likely to promote arbitrary and discriminatory action by public authorities and to undermine confidence in the proposition that international agreements are made to be kept, than the failure of the international community to abide by the maxim that no act can be punished as a crime unless there was in advance of the act a specific criminal law. ${ }^{14}$

This is, of course, a value judgment on which men differ. The position of the critics of Nuremberg is assailable not merely because of their particular choice of values but because they appear to have made that choice without considering the history and the purpose of the rule they invoke

\footnotetext{
${ }_{3}$ The Charter of the International Military Tribunal is set forth in I Nazi Conspiracy and Aggression 4.

${ }^{14}$ Wyzanski, Nuremberg in Retrospect, 778 Atlantic Monthly ${ }_{5}^{6}$ (Dec., I946).
} 
and the consequence of making it decisive in the particular context involved.

There may, however, be objection to the claim that there was a general and unequivocal condemnation of aggressive war. It may be said that it is easy first to postulate a so-called international community and then to misjudge its moral sentiments. We know only too well that the standards which are embodied in lawyers' documents are often not real in the world of international (or domestic) action. There may be argument that we are confusing formal standards with meaningful ones when we find a widely held repugnance for aggressive war prior to I939. War in Europe had been almost as natural a relation as peace. Disputes had been resolved by force, in part because international law had not offered an effective alternative for securing the redress of even a legitimate grievance. The tradition of aggression and its moral acceptance in an area bristling with long standing hates, fears, and rivalries, could not, it may be argued, be destroyed by a few formal pronouncements, such as the Kellogg-Briand Pact. Men did not object to aggression because they considered it wrong, but simply to an attack on their own country or on a country whose survival was identified with the interests of their country. In the actual environment of international relations, to talk of the moral condemnation of aggression is, we may be told, to find order and morality where only anarchy and amorality prevail.

The foregoing argument raises questions whose detailed handling requires a knowledge of history and psychology well beyond my equipment. My intuition is to reject it not merely because it is a counsel of despair and anarchy which would undermine every international agreement. It denies any meaning to the whole network of arrangements for the pacific settlement of disputes devised between two world wars. ${ }^{x 5}$ It disregards the most solemn, widespread, and unequivocal condemnations of aggression. It ignores the igniting appeal of the battle-cry "a war to end wars." It implies that a leader could have proclaimed a naked war of aggression to his people and received their applause. ${ }^{16}$ Even Hitler did not dare that expedient. ${ }^{x 7}$

xs Note $x 2$ supra.

${ }^{16}$ In this connection it is significant that, with the exception of Mussolini's attack on France in I940, almost all of the wars involving a major power, from Italy's attack on Ethiopia to Pearl Harbor, were justified by the aggressor nations as being in self-defense. The official Rome communique concerning the Italian attack against Ethiopia explained it as "necessary to repel the imminent Abyssinian threat." Burns, Ethiopia and Italy II (1935). Similarly, Japan, among other reasons, urged self-defense as a justification for its attack in Manchuria. See Japan's Case in the Sino-Japanese Dispute, Japan's Delegation to 
But even if this gJoomy approach had some basis in fact and even if there were a gap between the sentiment of the Pact of Paris and the actual sentiments of a substantial number of men or perhaps even of a majority of men, the enforcement of legal and moral standards which are higher than personal standards is one form of progress. Hypocrisy, it has been said, is an attempt to appear better than we are. The enforcement of a social standard which in this sense is hypocritical is an attempt to create a better social order. When a standard of conduct has been embodied and repeatedly reaffirmed, in the most solemn and unequivocal international formulations, it would be a dangerous invitation to anarchy to disavow it on the basis of doubtful conjectures as to the "real" state of international psychology. There is the same necessity in international law, which exists in the municipal law, to give controlling effect to objective standards.

The foregoing discussion has indicated that even if Nuremberg involved a retroactive aspect, it was not a situation where the ex post facto doctrine could be properly applied. There is, moreover, an adequate technical answer to the ex post facto charge-an answer that was suggested by $\mathrm{Mr}$. Justice Jackson in his opening statement ${ }^{18}$ and elaborated by $M$. de Menthon, the Chief Prosecutor for France. ${ }^{x 9}$ War, whether or not it is

the League of Nations 9I (1933). [The Italian and Japanese claims were rejected not only by the League of Nations but also by public opinion in the western world which loudly condemned Japanese and Italian aggression. 133 Nation 352 (I93 $\mathrm{x}$ ); x I 2 Literary Digest 5 (Jan. 23, I932); 26 Time $I 7$ (Dec. 2I, I935); I42 Catholic World 358-59 (r939)]. See note 17 infra for Germany's explanation of the German attack on Poland. The Soviet government's announcement concerning the Finnish war claimed that the Soviets were defending themselves against a Finnish military attack: 34 Time 24 (Dec. 4, 1939). Although the Japanese in attempting to justify Pearl Harbor did not explicitly claim a military attack by the United States, they did invoke the claim of self-defense. Hirohito's address, New York Times, p. 2, col. 2 (Dec. 8, I94I); Tojo's address, id. at p. 5, col. 7. Mussolini, however, did not seek to justify his attack on France in 1940 by claiming self-defense. 6 Vital Speeches 5 ro (r940). The significance of Mussolini's deviation is diluted by several considerations: ( $I$ ) The military position of his enemies was so desperate that a claim of self-defense would have been preposterous; (2) Mussolini was not starting a war but joining an ally whom the world bad already stigmatized as an aggressor.

${ }^{17}$ Hitler in his speech to the Reichstag after the German aggression against Poland sought to create the impression that the Poles had launched a military attack and that they were acting in self-defense. See de Roussy de Sales, Hitler, My New Order 687, 689 (I94r).

${ }^{18}$ I Nazi Conspiracy and Aggression $x 64$.

x9 In making this argument at Nuremberg the French Prosecutor presented a bit of Pascal's irony:

"Why do you kill me?"

"Don't you live on the other side of the water? My friend, if you lived on this side, I would be an assassin, and it would be unjust to kill you as I am doing, but since you live on the other side, I am an honorable man, and this is just." Transcript of International Military Tribunal, at $2890-9 x$. 
waged chivalrously, inherently involves a series of acts which for millennia have been denounced as crimes under every civilized legal system: deliberate mass killings, assaults, burning-acts that traditionally have been criminal even without the abominable sadism which the Nazis added. Prior to the Kellogg-Briand Pact and the international condemnation of war, these acts were nor punishable if they were an incident of any war, whether or not aggressive. Prior to these agreements, all wars were considered legitimate national activity, which conferred a privilege to kill and destroy. However, when the nations of the world condemned aggressive war they destroyed that privilege. Thereafter, when the charge of murder was made against the instigators of aggression, i.e., the instigators of deliberate mass killings, they could not urge war as a justification and a defense; $;^{20}$ the international community had solemnly declared that aggressive war was unjustified. Thus, for example, the deliberate killing of Frenchmen even in the course of a war involved a violation of the French laws against murder where the French had been the victims of aggression. Under this approach, the Kellogg-Briand Pact and similar agreements are important, not because they directly made aggressive war a crime, but because, by destroying it as a defense, they made the instigators of aggression subject to the universal laws against murder. ${ }^{2 x}$ It is these ancient laws which are the basis for the punishment of aggression prescribed by the Charter. This argument may, in view of the broad issues raised by Nuremberg, seem unduly technical, but when lawyers insist on flexing their legalisms, one technicality breeds another.

It may also be objected that this argument proves too much for it would make the common soldier of an aggressive nation as guilty as the chief of state. The criminal law has, however, customarily emphasized the knowledge and intention of the actor. The common soldier misled into the

${ }^{20}$ This argument was foreshadowed by Mr. Henry L. Stimson's analysis in 1932 of the legal effect of the Kellogg-Briand Pact.

"War between nations was renounced by the signatories of the Kellog-Briand Pact. This means that it has become illegal throughout practically the entire world. It is no longer to be the source and subject of rights. It is no longer to be the principle around which duties, the conduct, and the rights of nations revolve. It is an illegal thing. Hereafter when two nations engage in armed conflict either one or both of them must be wrongdoers-violators of this general treaty law. We no longer draw a circle about them and treat them with the punctilios of the duelist's code. Instead, we denounce them as lawbreakers. By that very act, we have made obsolete many legal precedents and have given the legal profession the task of reexamining many of its codes and treaties." See Glueck, op, cit. supra note I2, at 20-21.

${ }^{2 x}$ Under this view, the invaded countries which did not sign the Charter and were not represented on the Tribunal, in effect authorized the Tribunal to enforce their laws, by adhering to the Charter prior to the beginning of the trial. Eighteen nations in addition to the four powers who formulated the Charter have adhered to the Charter. Jackson, The Nuremberg Case I21 (1947). 
belief that he was defending his country could be distinguished from the leaders who knowingly planned and launched the aggression.

There is one further objection to the Charter's condemnation of aggressive war that is related to the ex post facto problem-the absence of a widely accepted definition of aggression. During the interval between the two world wars, there was a serious divergence as to whether a comprehensive definition of aggression should be laid down in advance. Opponents of such a definition feared that it might become a "guidepost for the guilty." Others urged that a definition of aggression, like definitions of crimes in municipal law, would promote certainty and security;2z and a number of states signed treaties incorporating such a definition. ${ }^{23}$ The Charter, however, neither adopted a pre-existing definition nor formulated a new one. It stated that aggression was a crime but did not state what aggression was.

There are, of course, serious problems in formulating an appropriate definition of aggression, particularly under modern conditions of warfare, international insecurity, and disorganization. The difficulty is especially acute in connection with a nation's rights to take action for what it considers to be self-defense-one of the points covered by the reservation of the United States and other countries to the Kellogg-Briand Pact.. ${ }^{24}$ The obvious danger is that the right to self-defense may be unilaterally construed as the right to protect any important national interest.

These issues, although serious as abstractions, were not real at Nuremberg. Anyone who studies the captured German documents, spread on record at Nuremberg, will be convinced of the absolute and unequivocal character of German aggression. ${ }^{25}$ No one who recalls the comparative military position of Germany and its victims in 1939 can seriously urge that Germany was in any danger of, or feared, an attack, or that the war Germany launched was defensive or preventive. ${ }^{26}$ Any doubt on that ques-

2 The problems involved in defining aggression are discussed in 2 Lauterpacht on Oppenheim's International Law 159-60 (I935), and authorities cited therein.

23 Ibid.

24 Ibid.; at 158; see also 20 Transactions of the Grotius Society 197-20I (1935).

25 × Nazi Conspiracy and Aggression x50-52, 673-733; Jackson, op. cit. supra note 21,

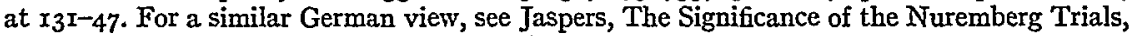
22 Notre Dame Lawyer I5O, I52-53 (1947).

${ }^{26}$ I Nazi Conspiracy and Aggression I5I, 680-97. Minister of War von Blomberg in a I937 directive stated: "The general political situation justifies the supposition that Germany need not consider an attack on any side. Grounds for this are, in addition to the lack of desire for war in almost all nations, particularly the Western Powers, the deficiencies in the preparedness for war in a number of states of Russia in particular." Jackson, op. cit. supra note 2r, at I5I. 
tion would, moreover, be quickly resolved by a reading of the captured documents. In short, there is no definition of aggression which does not clearly cover Germany's premeditated attack.

On further analysis, the ex post facto objection has some paradoxical features. Here it is necessary to recall the background of the provision in the Charter providing for individual punishment of the instigators of aggression. This is a melancholy necessity, but our memories seem so short and appear to have been so blunted by savagery on a monumental scale, that they must be refreshed. Reliable evidence had indicated that the war had begun as a deliberate attempt by the Nazis to conquer and dominate Europe and perhaps the world. Reliable evidence had indicated that the Nazis had progressively violated the rules and usages of war, and that their unparalleled violations could not be justified under the most expansive conception of military necessity.

This progressive abandonment of restraint and chivalry is typical of all wars, and infects, in varying degrees, both sides. It disturbed Grotius, ${ }^{27}$ and with even greater reason, must have profoundly disturbed the framers of the Charter. Although the enormity of Nazi sadism was clear, it was equally clear that the conventions regulating the waging of war are at best a fragile barrier between the violence of war and its victims. ${ }^{28}$ Moreover, with science's multiplication of horror, a modern war, no matter how chivalrous, involves so much misery that to punish deviations from the conventions without punishing the instigators of an aggressive war seems like a mocking exercise in gentlemanly futility. Accordingly, what was required was, as Mr. Justice Jackson emphasized, ${ }^{29}$ the recognition that the supreme evil and the supreme crime lay in the launching of a war of aggression. ${ }^{30}$

With this as a background, the Allies could have chosen from the following possibilities in deciding what action to take with respect to the whole course of Nazi conduct:

(I) To inflict no punishment either for crimes against the peace or for traditional war crimes.

(2) To inflict punishment only for violations of the rules of war, with or without granting the opportunity for defense traditionally extended before such punishment has been imposed.

27 West, Conscience and Society I86 (I945).

${ }^{28}$ Goering attacked the Rules of Land Warfare as obsolete and inapplicable to a nation fighting a modern war. Transcript of International Military Tribunal, 5980-8I. His point cannot be summarily dismissed.

${ }^{29}$ Transcript of International Military Tribunal, at 53 .

${ }^{30}$ The Tribunal concurred in this view. Ibid., at r6819. 
(3) In addition to punishing for war crimes, to administer punishment for aggression, but through "executive justice," that is, summary punishment without trial or opportunity for defense.

(4) To administer punishment for aggression (as well as "war crimes"), but only according to predetermined standards of guilt and after the accused had been given a fair opportunity to be heard so that the innocent would not be punished with the guilty. This alternative, which was embodied in the Charter, was eloquently justified by Mr. Justice Jackson in his report to the President. ${ }^{3 x}$

Critics of Nuremberg, might, of course, logically argue that no punishment should have been inflicted for the launching of aggression because of the alleged absence of a clear international understanding that such action was to constitute a punishable crime. But the critics generally have not adopted that position. They appear to approve punishment for the instigators of aggression..$^{32}$ What they condemn is the use of the judicial process in the application of criteria of guilt and in the determination of penalties. Such procedure, the argument goes, brings the judiciary and the whole ideal of the rule of law into disrepute.

This argument is in essence an objection to granting an accused the right to defend himself. It is an objection to precautionary measures designed to avoid mistakes-the condemning of men innocent under the applicable standards of guilt. It is inconsistent with the requirements

${ }^{3}$ "What shall we do with them? We could, of course, set them at large without a hearing. But it has cost unmeasured thousands of American lives to beat and bind these men. To free them without a trial would mock the dead and make cynics of the living. On the other hand, we could execute or otherwise punish them without a hearing. But undiscriminating executions or punishments without definite findings of guilt, fairly arrived at, would violate pledges repeatedly given, and would not set easily on the American conscience or be remembered by our children with pride. The only other course is to determine the innocence or guilt of the accused after a hearing as dispassionate as the times and horrors we deal with will permit, and upon a record that will leave our reasons and motives clear." Jackson, op. cit. supra note $2 \mathbf{r}$, at 8 .

${ }^{32}$ See, e.g., The Nurnberg Novelty, op. cit. supra note 2. In "The Nurnberg Novelty," the editors of Fortune Magazine, like many other critics of Nuremberg, point to the exile of Napoleon without trial as a precedent for the view that "executive justice" should have been administered to the top Nazis. There are, however, several significant differences in the two situations. The exile of one emperor raised completely different problems from those involved in devising a procedure for reaching all of the top Nazis indicted at Nuremberg (twenty-two) and the many more of intermediate importance who will be dealt with in subsequent proceedings on the basis of the principles embodied in the Charter. It, morever, is one thing to decree a tolerably pleasant exile for one man and another thing to condemn twenty-two leaders to execution without trial, as Fortune Magazine suggested. Finally, it may be appropriate to observe that in I8I5 the whole network of arrangements for pacific solution of international disputes and the Kellogg-Briand Pact had not yet been adopted. The Congress of Vienna may have resorted to "executive measures" only because society had not yet formulated a standard which could have been applied in a trial. 
of the Geneva Convention. ${ }^{33}$ It is the endorsement of lynch law on an international scale. As Judge Parker has said, there is nothing in law, morals, or common sense to commend it. ${ }^{34}$ The critics may label the Nuremberg trials as "political" rather than "legal," if by that they mean a program involving the judicial application of principles of guilt defined by the executive. But it is difficult to see how they can view Nuremberg as more objectionable than a program of organized violence summarily implemented by the executive through the army or some other executive organ.

There is another curious feature in the critics apparent preference for ex parte condemnation without trial-the notion that the judiciary is brought into disrepute no matter how fair and dignified the trial it provides. No one who examines the Nuremberg record and the verdict, as many of the critics have not, will question the disinterestedness and the fairness of the Tribunal. Nevertheless, disrepute is said to result from the judges' application of (allegedly) ex post facto law. In the case at hand it should be observed that even if the law were ex post facto, the judges did not make it. They simply applied the law formulated and embodied in the Charter by the executive representatives of the four Allied powers, in the same fashion as an administrative tribunal under American law applies the mandate of the legislature which created it. If there is to be criticism, it should be based on the fact that the executive made an ex post facto principle controlling, and not on the fact that the executive established a court to apply the principles in the light of the evidence produced at a fair trial. Defendants who are given a right to be heard may prove that even an allegedly retroactive standard is not applicable to them. How much more justification the criticism would have if the executive had not only formulated such a standard but had insisted on its application without the traditional guarantees which we extended to the domestic criminal or the conventional war criminal who has been caught red-handed.

${ }_{33}$ Passing the question of whether all of the provisions of the Geneva Convention of 1929 continue to operate after hostilities have ended [see in the Matter of Yamashita, 327 U.S. $x, 76$ (1946)] every consideration behind the convention's requirement (Articles 54,6r, 66, 83) that prisoners of war accused of war crimes while hostilities are in progress be accorded a trial operates even though hostilities have ended. There is, moreover, an additional consideration for insisting on a trial after hostilities are ended. The fear of immediate reprisal against his own forces no longer operates to check arbitrary action by the captor.

Under the foregoing view, Mr. Justice Jackson's argument that the prisoners at Nuremberg, but for the Charter, would not have been entitled to any trial at all is open to question. Jackson, op. cit. supra note 21 , at $\times 2$. The prisoners could have invoked the Geneva Convention. See Ex Parte Quirin, 3I7 U.S. I, 25 (1942).

34 Parker, the Nuremberg Trial, 30 Am. Jud. Soc. Io9, Ir3 (I946). 
The Tribunal had not only the function of insuring a fair trial but also of applying the vague principles of guilt written into the Charter. The Charter did not, unfortunately perhaps, expressly provide for discrimination between the major planners and instigators of aggression and the large bulk of the German people. Article 6a made the preparation, initiation, or waging of a war of aggression a crime against the peace. Read literally, it would have made every German who had worked in a war plant or had fought as a common soldier guilty of an international crime. The application of any such all-inclusive standard of guilt would have been objectionable. It would have ignored differences in power, knowledge, and freedom of choice, considerations which should be reflected in the application of standards of guilt. Accordingly, Mr. Justice Jackson in his opening statement ${ }^{35}$ made it clear that the prosecutions' charges, insofar as they were based on Article 6a of the Charter, were directed only at the men who with knowledge had played major roles in the planning, launching, or waging of the Nazi war of aggression.

The Tribunal, in applying section 6a, imposed even greater limitations. Thus, Fritsche, who had been chief of radio propaganda throughout the war, was nevertheless acquitted (with the Soviet judge dissenting), because his role had been a comparatively insignificant one. ${ }^{36}$ Moreover, Schacht, who had exercised broad powers in the economic-military field and who had made a central contribution to German rearmament as Minister of Economics and Plenip̉otentiary for Defense until I937, and as President of the Reichsbank until 1939 , was also acquitted because the Tribunal (with the Soviet judge again dissenting) was not satisfied that Schacht had been aware of a specific purpose to use the military machine for aggression. ${ }^{37}$ Similarly, Funk, who had succeeded Schacht as Minister of Economics and as Plenipotentiary and who was found guilty of all the crimes defined by the Charter, including the ghoulish crime of arranging for the extraction of the gold fillings of concentration camp victims, was not condemned to death because his power and influence were dwarfed by the tremendous authority of Goering, his chief..$^{8}$

The limitations imposed by the Tribunal, which emphasized knowledge, influence, and the power to resist the compulsions of a police state, are particularly appropriate when charges of criminality are met with a defense which stresses coercion by the state. Exponents of executive

${ }^{35}$ Jackson, op. cit. supra note $2 x$, at 33,36 .

${ }^{36}$ Transcript of International Military Tribunal, at x7068-69.

37 Ibid., at 17022 .

${ }^{38} \mathrm{Ibid}$., at $170 \mathrm{3} 3$, $170 \mathrm{r} 6$. 
punishment would, I believe, approve the general criteria of limitation applied by the Tribunal however much debate there may be regarding the merits of the particular applications. Yet in the absence of the crystallization of specific issues as the result of taking of evidence and the opportunity for defense in an adversary proceeding, these necessary distinctions might not have been made.

Professor Rheinstein finds, we have seen, a causal relationship between the Nuremberg trials and action on the part of the German Länder under the direction of the United States Military Government which he believes is arbitrary. This is not an appropriate place for a discussion of the merits of the denazification program. It does seem appropriate to observe that there is no evidence that the granting of a fair hearing at Nuremberg has promoted excesses in the denazification program. A priori, the opposite conclusion would seem in order. "It is not too much to hope," said Mr. Justice Jackson, "that this example of full and fair hearing, and tranquil and discriminating judgment will do something toward strengthening the processes of justice in many countries." 39 Moreover, the history of every defeated country and every liberated one suggests that excesses are the unavoidable accompaniment of readjustment. Quite apart from Nuremberg, there is no reason to expect Germany to avoid this incident of recovery from chaos. Nor is there any justification for a modern myth that would make Nuremberg the Pandora's box of occupation difficulties.

It is true, as Professor Rheinstein suggests, that Germans at Nuremberg and under the denazification program have been punished for acts that were not only legal but praiseworthy under the Nazi law. The attack on Poland, Belsen, Buchenwald, Auschwitz, the enslavement and degradation of foreign labor, the whole train of organized outrage revealed by the record at Nuremberg, was legal and praiseworthy under the Nazi system. Indeed, it was the Nazi system. Yet the defendants themselves recognized that their own law could not override the requirements of international law and human decency, Hans Frank, formerly GovernorGeneral of Poland, in his testimony before the tribunal stated: "A thousand years will pass and this guilt of Germany [for the extermination of the Jews] will still not be erased." $4^{\circ}$ The intimation that legality under the Nazi legal system should be a defense against international accountability is in essence a suggestion that we abandon all of the rules which have been painfully evolved to mitigate the excesses of war and to outlaw it.

39 Final report to the President, quoted in Jackson, op. cit. supra note 2r, at xvi.

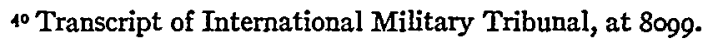


The logic of this suggestion again leads to the conclusion that the Nazis be immune from any punishment whatever..$^{4 x}$

Professor Rheinstein also finds that Nuremberg has impeded the restoration of law and order in Germany. One can speculate regarding the impact of Nuremberg on the imagination of thoughtful Germans.42 The rubble of German cities and the regime of misery which is the legacy of - Nazi aggression might, one would be entitled to hope, persuade the Germans that the architects of their chaos deserved punishment. In any event, one German philosopher, although recognizing, as all thoughtful men have, the difficulties of enforcing international standards of conduct in our primitive international order, has blessed the trials. ${ }^{43}$ Whatever the state of German cynicism about law and order and democracy, it is doubtful that the Nuremberg procedure has depreciated those ideals in the German imagination. Would the Germans have been less cynical about law and order if the Allies immediately after the war had drawn up an ex parte execution list without providing for judicial determination of guilt? There is not the slightest shred of proof that any of the other possible methods of dealing with the Nazi leaders would have made a greater contribution to the reintegration of Germany into the civilized world.

There is one criticism in the current debate which is more troublesome.

${ }_{4}$ I wish to make it clear that Professor Rheinstein in his book, review did not take the position that "legality" under the Nazi system should be a defense to the Nazi leaders who had decreed that torture, murder, and inhumanity should be "legal." He has, moreover, in conversation, emphasized that in his view this defense should be open only to the mass of little fellows. Although a distinction between the Nazi leaders and the Nazi masses is desirable (see supra, p. 466), it would not be desirable to rest the protection of insignificant Nazis on the ground that their conduct was "legal" under the Nazi system. Such a justification too easily becomes a plea of superior orders and tends to ignore the quality of the allegedly legal acts. A hypothetical case will illustrate the nature of the difficulty: suppose a German concentration camp guard acting "legally" deliberately tortured and killed Poles in the camp. Should the combination of the guard's insignificance and the "legality" of his conduct automatically immunize him? Even making the further assumption, that the guard was acting under specific orders and that his disobedience might have meant his death, we know from the life-boat cases and the rules of war, that self-preservation is not necessarily the final law. Cf. Hitchler, Necessity as a Defense in Criminal Cases, 33 Dick. L. Rev. I38 (I929); 50 Harv. L. Rev. 982 (r937); Cal. Pen. Code (Deering, r937) § 26; Sophocles, Antigone.

International prosecution of action required by the commands of a police state raises a serious ethical problem which becomes more acute as prosecution moves away from the leaders. The proper treatment of this problem would in my judgment require a more flexible and discriminating standard than legality under the Nazi system even if that standard were applied in the light of the actor's knowledge and responsibility.

42 Informal advice from the Department of State indicates that polls have been conducted among the Germans to determine their reaction to the Nuremberg trials. Unfortunately, the Department could not make the results of these polls available in time for inclusion in this note.

${ }^{43}$ Jaspers, op. cit. supra note $2 \pi$. 
It is, in my judgment, the central difficulty of Nuremberg: The governing law has not been equally applied. The standards of guilt have been applied only to the enemy. They have not been applied to our Allies or to ourselves. The Russians are not forced to defend their operations in Finland or Poland. We are not required to justify Hiroshima. ${ }^{44}$ The barbarity of the Nazis and the fact that it was their aggression which unleashed the whole chain of horrors strengthens our relative moral position. But while this justifies the actual application of a unilateral standard at Nuremberg it cannot conceal the imperfect character of such a standard.

Nuremberg, however, merely reflects that inequality; it did not produce it. The inequality is the product of a primitive international order. The victor, long before Nuremberg, has applied a unilateral standard in, for example, dealing with traditional war crimes. He has punished the unchivalrous conduct of the enemy; the same conduct by his own forces has largely gone unpunished. Unless we had been prepared to comb our own ranks for violators of the rules of war, the logic of the inequality argument would have required us to give the Nazis complete immunity, for all of their crimes-traditional war crimes as well as crimes against the peace. Even the critics shrink from this position. We can justifiably abandon it for the reasons already given, the enormous greater depravity of the Nazis, and the fact that they deliberately launched the aggression without which our comparatively minor deviations from accepted usages would not have occurred.

This inequality will persist until we have succeeded in the central task of our time-the building of a just, universal, and enforceable system of international law. The Nuremberg trials, like the San Francisco Conference, should be viewed as a dedication to this task. Nuremberg can be an important symbol helping in its achievement. And if we succeed, Nuremberg will stand as a great landmark in the struggle for an orderly, peaceful, and just international system. If we fail, we shall hear again-and this time from the rubble of the world-an attack on Nuremberg as power pretending to be justice. I946).

14 See Compton, If the Atomic Bomb Had Not Been Used, I78 Atlantic Monthly 54 (Dec., 